\title{
New host reports of rust fungi (Pucciniales) from Khyber Pakhtunkhwa, Pakistan
}

\section{Fahad $M^{1^{*}}$, Fiaz $M^{1}$, Ullah $Z^{1}$, Shariq $M^{1}$, Ullah $S^{1}$, Rehman $\mathbf{H U}^{1}$, Shah $\mathbf{R}^{1}$, Ahmad $S^{2}$}

\author{
${ }^{1}$ Department of Botany, Hazara University Mansehra, Khyber Pakhtunkhwa, Pakistan 21300. \\ ${ }^{2}$ Govt PG Jehan Zeb Collage saidu sharif Swat,
}

Fahad M, Fiaz M, Ullah Z, Shariq M, Ullah S, Rehman Hu, Shah R, Ahmad S 2019 - New host reports of rust fungi (Pucciniales) from Khyber Pakhtunkhwa, Pakistan. Plant Pathology \& Quarantine 9(1), 72-76, Doi 10.5943/ppq/9/1/8

\begin{abstract}
During a survey of rust fungi from Shangla District of Khyber Pakutunkhwa, Pakistan, two species of Puccinia were found parasitizing two plant species. Puccinia purpurea was found on Sorghum halepense, and P. caricis-filicinae was found on Carex filicina. Sorghum halepense is reported as new host from Pakistan while P. caricis-filicinae is a new record from District Shangla (KP) Pakistan.
\end{abstract}

Keywords - Cyperaceae - grass - Poaceae - Puccinia - rusts

\section{Introduction}

Rust fungi (Pucciniales) are one of the largest and most diverse groups of plant pathogens and can affect almost all plants in the biosphere (Cummins \& Hiratsuka 2003). Puccinia is the largest genus in Pucciniales and comprises more than 4,000 species. The genus is characterized by producing pedicillate and two-celled teliospores (Mahadevakumar et al. 2016). District Shangla lies in the moist temperate range of the Himalayan forests and is floristically very rich. Khyber Pakhtunkhwa (KP), formerly known as the Northwest Frontier Province (NWFP), is one of five provinces of Pakistan, located in the Northwest of the country. It is situated at approximately $34.00^{\circ} \mathrm{N}, 71.32^{\circ} \mathrm{E}$. The area is famous for hill coniferous forests, herbal plants, and large biodiversity. This is a floristically rich area with many plant diseases such as leaf blights, smuts and rust. Although only one rust fungus is known from District Shangla, this number is not significant as there are many potential host plant species in this region (Ono 1992, Ahmad et al. 1997, Afshan et al. 2008). About 183 species of rust fungi have been reported from Khyber Pakhtunkhwa (Afshan \& Khalid 2009, Afshan et al. 2008, Ishaq et al. 2013, Fiaz et al. 2017, Ullah 2018). During exploration of Pucciniales of Khyber Pakhtunkhwa, rust infected plants were collected from Shangla District. Among these, Puccinia caricis-filicinae on Carex filicina is a new record for Shangla District (KP), Pakistan while P. purpurea on Sorghum halepense is reported as a new record for Pakistan.

\section{Materials \& Methods}

Freehand sections and sori of infected plant materials were mounted in lactic acid. The plants 
were photographed and infected portions were observed using a stereomicroscope. At least 25 spores of each spore state were examined using a microscope (Nikon YS 100) and paraphyses and spore dimensions were made using an ocular micrometer (Zeiss eyepiece screw micrometer). Sections and spores were microphotographed by digiporo-Labomed. Illustrations were made using a Lucida camera (Ernst LeitzWetzlar, Germany). The rust specimens have been deposited in the herbarium of the Botany Department, at Hazara University Mansehra (KP) (HUP).

\section{Results and Discussion}

Puccinia purpurea Cooke, Grevillea 5: 15, 1876

Figs 1,2

Spermogonia and aecia not found. Uredinia mostly abaxial in leaves, on purple spots, $0.3 \times$ $0.5 \mathrm{~mm}$. Urediniospores chestnut brown, mostly hyaline or yellowish, $(26-) 31-40 \times 23-30(-32)$ $\mu \mathrm{m}$, wall $2 \mu \mathrm{m}$ thick, germ pores 5-8, scattered. Paraphyses present, up to $27 \mu \mathrm{m}$ long. Telia blackish brown, $0.5 \times 0.6 \mathrm{~mm}$, pulvinate, compact, exposed. Teliospores oblong-ellipsoid, 25-39 $\times$ 18-25 $\mu \mathrm{m}$, wall 2.5-3. $5 \mu \mathrm{m}$ thick; pedicel up to $47 \mu \mathrm{m}$ long.

Material examined - Pakistan, KP Province, District Shangla Kormang, $1900 \mathrm{~m}$ a.s.l., on Sorghum halepense with stage II and III, November 2016, Muhammad Fahad MF \# FR-119(HUP Herbarium No. MFR L-F 19).

Puccinia purpurea has been previously reported on Sorghum vulgare from Landi, Krachi, Lahore, Brain River Islamabad (Ahmad 1956a, b, Kakishima et al. 1959, Ghaffar \& Kafi 1968, Kakishima et al. 1993a, b). However, Sorghum halepense is a new host for Pakistan.

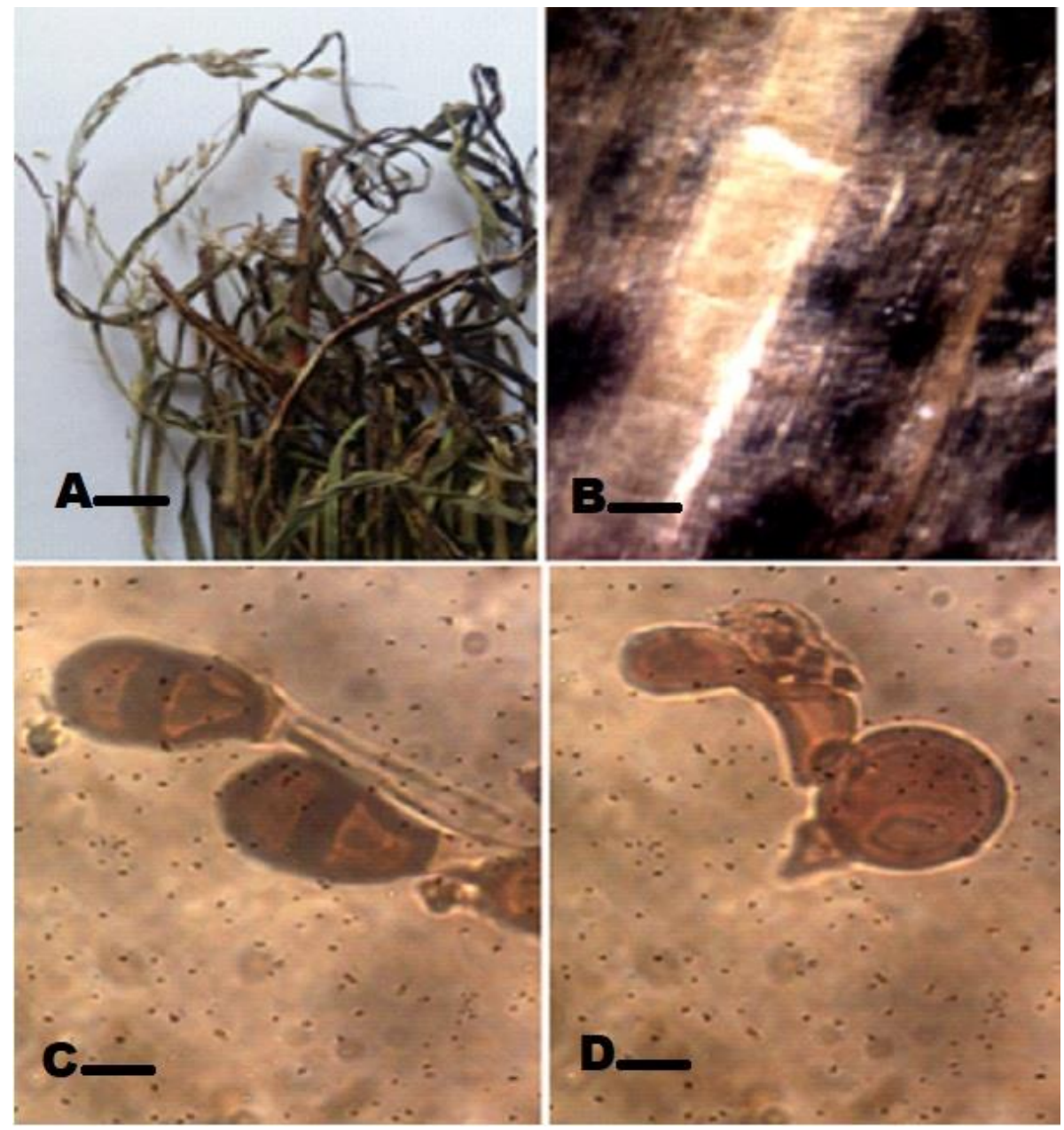

Fig. 1 - Puccinia purpurea on Sorghum halepense. A. Infected leaves of host plant. B. Telia and uredinia on abaxial leaf surface. C. Teliospores. D. Urediniospore and paraphysis. Scale bars: A = 5 $\mathrm{cm}, \mathrm{B}=5 \mathrm{~mm}, \mathrm{C}, \mathrm{D}=10 \mu \mathrm{m}$. 

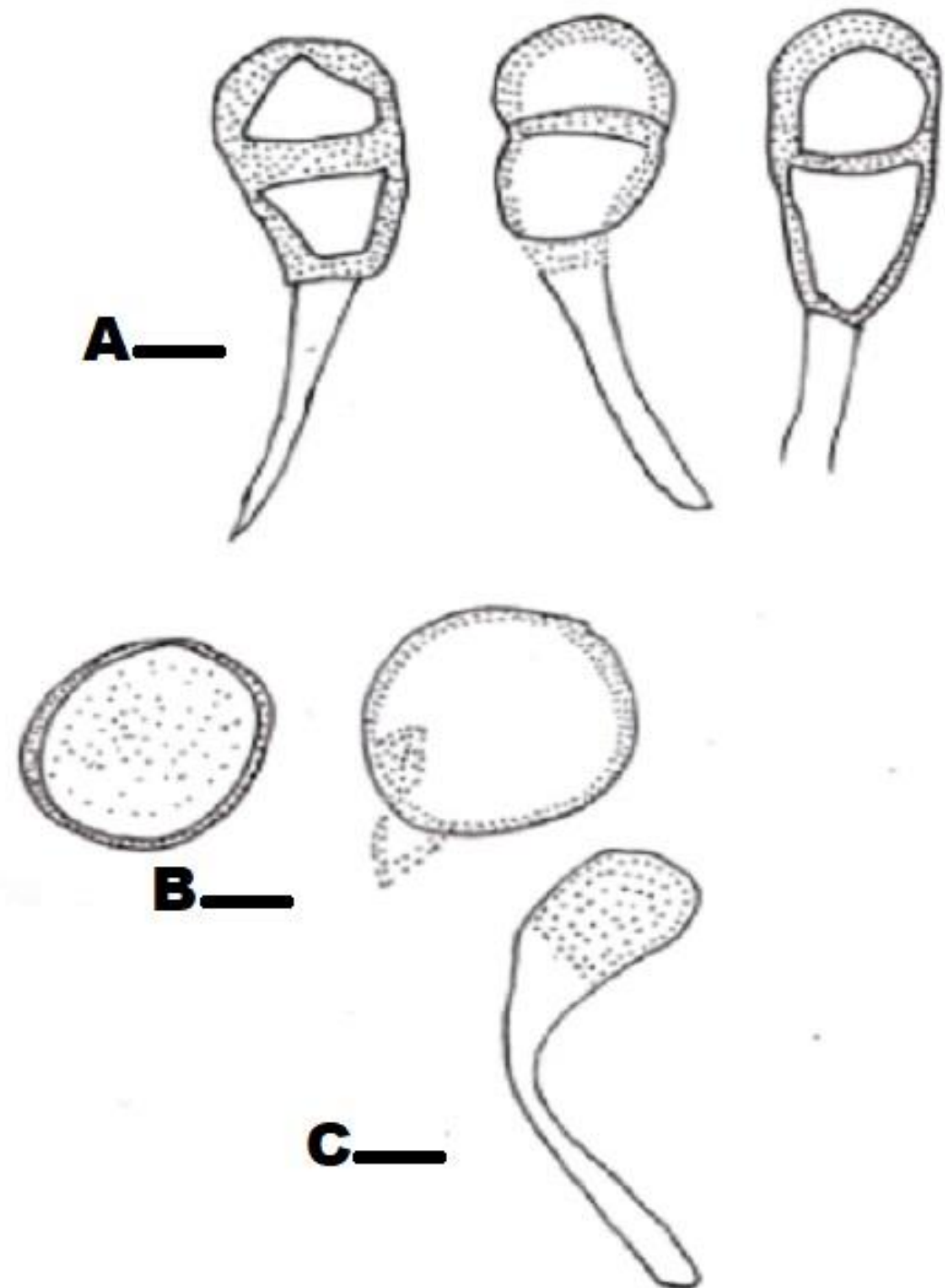

Fig. 2 - Puccinia purpurea. A Teliospores. B Urediniospores. C Paraphysis. Scale bars: A, C = $9 \mu \mathrm{m}$, $\mathrm{B}=7 \mu \mathrm{m}$.

Puccinia caricis-filicinae Barclay 1889

Figs 3, 4

Aecia and spermogonia unknown. Uredinia dark brown, amphigenous, Scattered, pulvinate, orbicular, $0.7 \mathrm{~mm}$ diameter. Urediniospores cinnamon brown, ovoid or ellipsoid, 21-35 $\times 17-22.7$ $\mu \mathrm{m}$, wall 1.7-2.5 $\mu \mathrm{m}$ thick, germ pores obscure. Telia dark brown, amphigenous, scattered, orbicular, $0.5 \mathrm{~mm}$ diameter. Teliospores oblong-clavate, oblong, rarely conically attenuate at the apex, rounded or often attenuate at the base, smooth, cinnamon brown, 35-48 $\times 12-18 \mu \mathrm{m}$; pedicel subhyaline apically, persistent, 7.5-46 ×5-8 $\mu \mathrm{m}$.

Material examined - Pakistan, KP Province, District Shangla Kormang, 1900 m a.s.l., on Carex filicina with stage II and III, November 2016, Muhammad Fahad MF \# FR-110 (HUP Herbarium No. MFR L-F 10).

Puccinia caricis-filicinae has been reported on Carex filicina from Nees, Muree (Khalid \& Iqbal 1996a) and from Kaghan Valley (Saba \& Khalid 2011). This is a new report from Shangla district. 


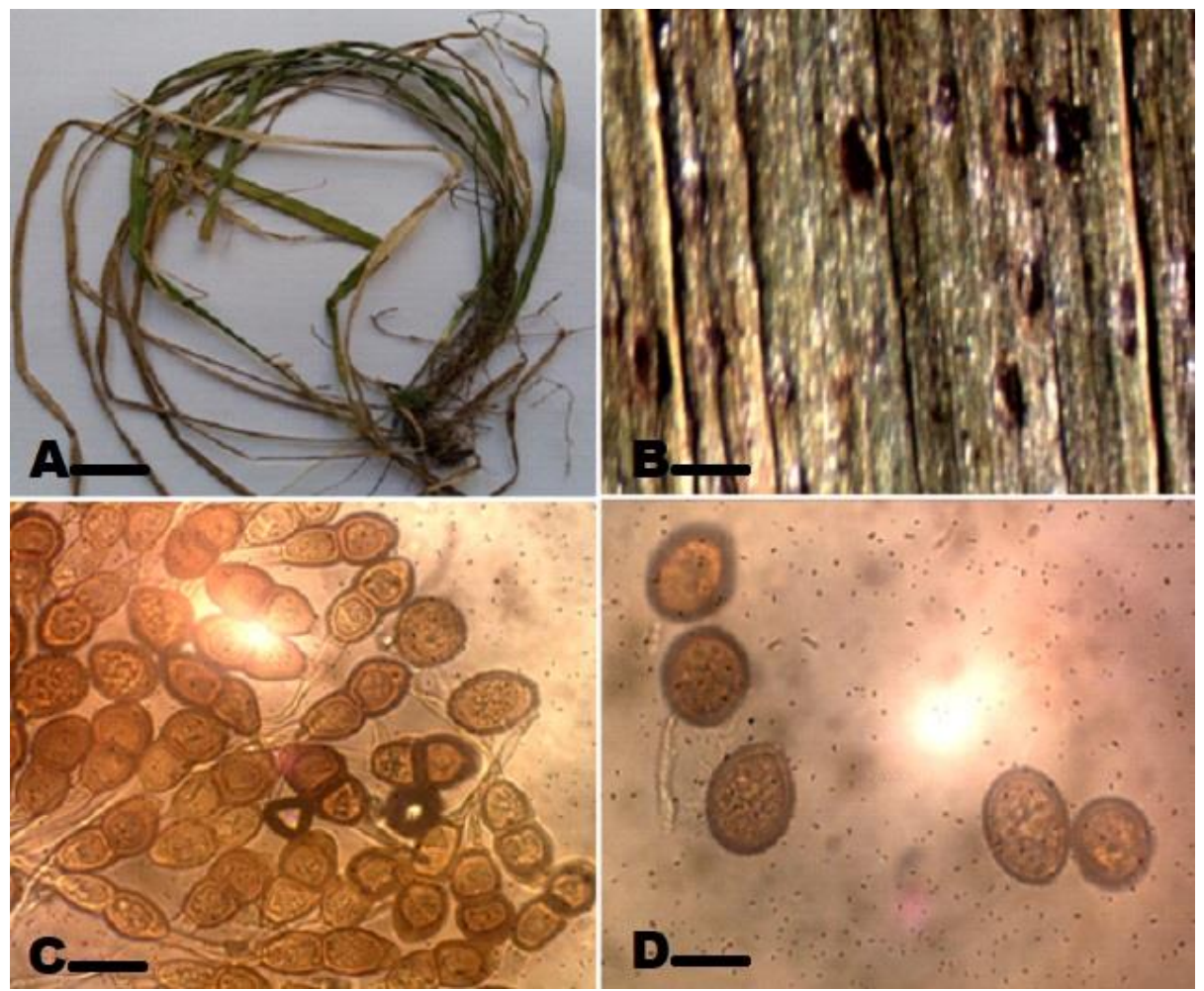

Fig. 3 - Puccinia caricis-filicinae on Carex filicina A Infected leaves of the host plant. B Telia and uredinia on leaf. C Teliospores. D Urediniospores. Scale bars: $A=3 \mathrm{~cm}, \mathrm{~B}=5 \mathrm{~mm}, \mathrm{C}=10 \mu \mathrm{m}, \mathrm{D}$ $=6 \mu \mathrm{m}$.

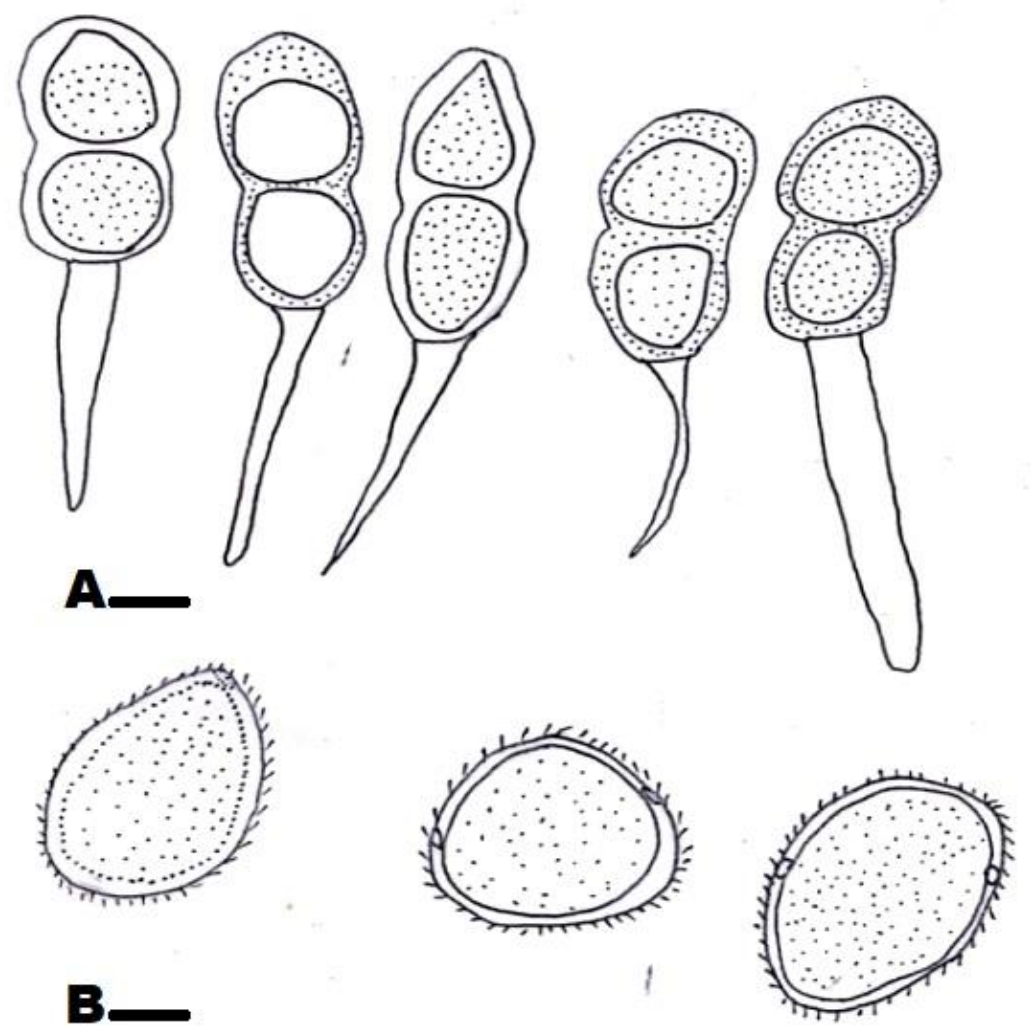

Fig. 4 - Puccinia caricis-filicinae A. Teliospores. B. Urediniospores. Scale bars: A = $10 \mu \mathrm{m}, \mathrm{B}=6$ $\mu \mathrm{m}$. 


\section{References}

Afshan NS, Khalid AN. 2009 - New records of Puccinia and Pucciniastrum from Pakistan. Mycotaxon 108, 137-146.

Afshan NS, Khalid AN, Niazi AR. 2008 - New records and distribution of rust fungi from Pakistan. Mycotaxon 105, 257-267.

Ahmad S. 1956a - Uredinales of Pakistan. Biologia 2, 29-101.

Ahmad S. 1956b - Fungi of Pakistan. Biological Society of Pakistan, Lahore Monograph 1, 1-126.

Ahmad S, Iqbal SH, Khalid AN. 1997 - Fungi of Pakistan. Sultan Ahmad Mycological Society of Pakistan, Lahore.

Cummins GB, Hiratsuka Y. 2003 - Illustrated genera of rust fungi. Third edition, APS Press, St. Paul, MN pp. 1-29.

Fiaz M, Habib A, Najam US. 2017 - New reports and host records of rust fungi from Pakistan. Bangladesh Journal of Botany 46(1), 73-81.

Ghaffar A, Kafi A. 1968 - Fungi of Karachi. Pakistan Journal of Science 20, 5-10.

Ishaq A, Afshan NS, Khalid AN. 2013 - New records of Puccinia on Poaceae from Khyber Pakhtunkhwa, Pakistan. Mycotaxon 126, 177-182.

Kakishima M, Okane I, Ono Y. 1993a - Rust fungi (Uredinales) of Pakistan collected in 1991. Cryptogamic Flora of Pakistan 2, 169-179.

Kakishima M, Okane I, Ono Y. 1993b - Graminicolous rust fungi (Uredinales) from Pakistan. Cryptogamic Flora of Pakistan 2, 181-186.

Khalid AN, Iqbal SH. 1996 - Additions to the rust flora of Pakistan. Pakistan Journal of Botany 28, 114-117.

Mahadevakumar S, Szabo LJ, Eilam T, Anikster Y, Janardhana GR. 2016 - A new rust disease on wild coffee (Psychotria nervosa) caused by Puccinia mysuruensis sp. nov. Plant Disease 100(7), 1371-1378.

Ono Y. 1992 - Uredinales collected in the Kaghan Valley, Pakistan. Cryptogamic Flora of Pakistan $1,217-240$.

Ullah S. 2018 - Studies on Diversity of Basidiomycetes of District Shangla. PhD Thesis, Department of Botany, Hazara University Mansehra, Pp. 10-20. 